\title{
Effect of Hormone Administration on the Sialylation and Fucosylation of Intestinal Microvillus Membranes of Suckling Rats ${ }^{1}$
}

\author{
AKHTAR MAHMOOD 2 AND RAMON TORRES-PINEDO
}

Department of Pediatrics, Pediatric Gastroenterology and Nutrition Section, University of Oklahoma Health Sciences Center, Oklahoma City, Oklahoma, 73126

\begin{abstract}
Cortisone, thyroxine, epidermal growth factor, or insulin were administered to 8-day-old rats for 4 days. In comparison to saline-injected controls, cortisone treatment: 1) lowered the sialic acid and raised the fucose content of the intestinal microvillus membranes, 2) increased ${ }^{3} \mathrm{H} \mid$ fucose incorporation into these membranes, and 3 ) decreased the membrane binding of ${ }^{125} \mathrm{I}$-wheat germ agglutinin, while increasing the binding of ${ }^{125} \mathrm{I}-u$ lex europeus agglutinin $I$ and ${ }^{125} I$-peanut agglutinin. Thyroxine treatment had similar effects on fucose content and ${ }^{125}$ Iulex europeus agglutinin I binding, but did not alter $\left[{ }^{3} \mathrm{H}\right]$ fucose incorporation or sialic acid content. At the doses used, epidermal growth factor and insulin had no significant effects. The effect of cortisone treatment on sialic acid and fucose was commensurate with a 5- to 6-day acceleration of postnatal intestinal maturation. The changes in lectin binding, however, suggested qualitative differences between developmental and cortisone-induced membrane glycosylation. In addition, this study demonstrates significant quantitative and qualitative differences in the response of intestinal glycosylation to pharmacologic doses of the four hormones. (Pediatr Res 19: 899-902, 1985)
\end{abstract}

\section{Abbreviations}

PNA, peanut agglutinin

UEA $A_{I}$, ulex europeus agglutinin I

WGA, wheat germ agglutinin

EGF, epidermal growth factor

The microvillus membrane of rat small intestine undergoes significant changes in glycosylation during postnatal development (1-5). Specifically, its sialic acid content decreases sharply during the third postnatal week, while fucose begins to rise toward the high levels attained after weaning (5). These developmental alterations in the type of terminal substitutions in oligosaccharides are probably responsible for significant changes in the electrical properties of the microvillus surface (5). Since the agerelated progress of the microvillus membrane fucosylation-desialylation process is quite similar to that described for the disaccharidase activities $(6,7)$, as well as for certain brush border transport functions $(8,9)$, the question arose as to whether this

Received January 14. 1985: accepted April 15. 1985.

Reprint requests Ramon Torres-Pincdo, M.D. Professor of Pediatrics, Oklahoma Children's Memorial Hospital, P.O. Box 26307, Oklahoma City. OK 73126.

Supported by Grant HD-12441 from the National Institute of Health.

${ }_{1}$ Presented in part at the annual meeting of the American Pediatric Society and the Society for Pediatric Research. Washington. D.C., May 3-6, 1983.

${ }^{2}$ Present addess Department of Biochemistry, Panjab University, Chandigarh14, 160014, India. process would also be influenced by pharmacologic doses of hormones (9-13). To examine this possibility, we injected suckling rats with cortisone, thyroxine, EGF, or insulin and measured the effect on the membrane content of sialic acid and fucose. In addition, the membrane reactivities associated with either the presence or disappearance of these saccharide residues were assessed through the use of lectins $(4,5)$.

\section{MATERIALS AND METHODS}

Litters of 8-day-old Sprague-Dawley rats (blood group AB; negative) were injected hormones daily for 4 days as follows: cortisone $(5 \mathrm{mg} / 100 \mathrm{~g}$ body weight, intramuscular); thyroxine (25 $\mu \mathrm{g} / 100 \mathrm{~g}$, intraperitoneal); EGF $(0.8 \mu \mathrm{g} / \mathrm{g}$, subcutaneous); and insulin (12 mU/g, subcutaneous). Age-matched controls received saline. The animals were fasted overnight and sacrificed under ether anesthesia. Starting from the ligament of Treitz, the proximal two-thirds of the small intestine was removed and flushed with ice-cold saline. The microvillus membranes were isolated and purified by the method of Schmitz et al. (14). The membranes, suspended in $50 \mathrm{mM}$ sodium maleate $\mathrm{pH} 6.5$, exhibited a 13- to 16-fold enrichment of lactase (suckling animals) and sucrase (adult animals) activities over the crude homogenate. Protein was determined by the method of Lowry et al. (15).

The fucose content of the membranes was measured colorimetrically (16) after initial hydrolysis with $0.1 \mathrm{~N} \mathrm{H}_{2} \mathrm{SO}_{4}$ for $4 \mathrm{~h}$ at $100^{\circ} \mathrm{C}$. Sialic acid was determined (17) after digesting the membranes with $0.1 \mathrm{~N} \mathrm{H}_{2} \mathrm{SO}_{4}$ for $1 \mathrm{~h}$ at $80^{\circ} \mathrm{C}$. Incorporation of $\left[{ }^{3} \mathrm{H}\right]$ fucose into the microvillus membranes was determined after injecting $0.6 \mu \mathrm{Ci}$ of the labeled sugar per gram body weight intraperitoneally. The animals were sacrificed $90 \mathrm{~min}$ after injection, the microvillus membranes isolated from the proximal half of the small intestine, digested in $10 \% \mathrm{KOH}$, and counted after adding $10 \mathrm{ml}$ of Aquasol (New England Nuclear, Boston, MA).

Lectin binding assays. PNA, UEA , and WGA were labeled with $\mathrm{Na}^{125}$ I using the Enzymobead Kit (BioRad Labs, Richmond, CA), as previously described (4). The specific activity of the labeled lectins was $2-4 \times 10^{4} \mathrm{cpm} / \mu \mathrm{g}$ protein. Lectin binding to the microvillus membranes was measured by incubating ${ }^{125} \mathrm{I}$ lectin $(1.0-2.8 \mu \mathrm{g})$, microvillus membranes $(10-20 \mu \mathrm{g}$ protein), and phosphate buffered saline pH 7.4 in a total volume of 200 $\mu \mathrm{l}$. The mixture was incubated for $30 \mathrm{~min}$ at $24^{\circ} \mathrm{C}$, and the reaction stopped by adding $2 \mathrm{ml}$ of phosphate-buffered saline and filtering through a $0.2 \mu \mathrm{m}$ Millipore filter (EGWP, Millipore Corp., Bedford, MA) under suction. The filter was washed twice with $4 \mathrm{ml}$ of cold phosphate-buffered saline, and the radioactivity counted in a Packard $\gamma$ spectrometer. Nonspecific binding to the membrane, measured in the presence of $0.15 \mathrm{M}$ lactose (PNA), $\alpha$-L-fucose $\left(\mathrm{UEA}_{\mathrm{I}}\right.$ ) or $\mathrm{N}$-acetylglucosamine (WGA), was negligible for the three lectins. Binding to the filters was less than $1 \%$ 
of the total radioactivity in the reagent mixture for $U E A_{I}$ and PNA, and $6 \%$ for WGA. Neuraminidase treatment of the microvillus membranes was performed as previously described (5).

Reagents. All reagents were analytical grade. The lectins were obtained from Sigma (St. Louis, MO). Na ${ }^{125} \mathrm{I}$, and $\left[{ }^{3} \mathrm{H}\right]-(5,6)-\mathrm{L}-$ fucose (sp. act. $56.0 \mathrm{Ci} / \mathrm{mmol}$ ) were from New England Nuclear. Neuraminidase from Clostridium perfrigens was obtained from Sigma, cortisone acetate was from Merck Sharp \& Dohme (West Point, PA), thyroxine (Levothroid) from Armour Pharmaceutical (Kankakec, IL), EGF (mouse submaxillary gland) from Sigma, and insulin from E. R. Squibb \& Sons (Princeton, NJ).

Statistics. Hormone-treated animals were compared to matched saline-injected controls using Student's $t$ test.

\section{RESULTS}

As shown in Table 1, there were significant differences in the effects of the various hormones on body and intestinal weights, as well as on disaccharidase activities. Animals treated with cortisone, but not with any of the other hormones, showed lower body and intestinal weights than controls. Cortisone and thyroxine induced the expected precocious rise in sucrase activity, while cortisone and EGF caused significant rises in lactase activity.

Table 2 shows the sialic acid and fucose content of the microvillus membranes in the experimental groups, as well as the values found at three stages of postnatal development. The values in saline-injected controls were similar to those previously reported by us in 12- to 14-day-old rats (5). In comparison, cortisone treatment decreased the sialic acid and increased the fucose content of the membranes, shifting their molar ratios in the direction of the mature animals. The values were equivalent to those normally found in postnatal day $17-18$, representing a 5- to 6-day acceleration of this developmental change in glycosylation. Thyroxine treatment had an effect on fucose content similar to cortisone, but differed from this hormone by not altering sialic acid significantly. EGF and insulin administration did not induce significant changes in any of the two sugars. The effect of the various hormonal treatments on fucosylation was further assessed as shown in Table 3. In agreement with others (3), we have found $\left[{ }^{3} \mathrm{H}\right]$ fucose incorporation into the microvillus membrane of suckling rats to reach a plateau between 1 and $2 \mathrm{~h}$ after intraperitoneal injection. Thus, we used a 90 -min pulse of the labeled sugar to compare hormone-treated animals with controls. The amount of $\left[{ }^{3} \mathrm{H}\right]$ fucose incorporated into the membranes of cortisone-treated animals was three times as high as in controls, approaching the levels of incorporation found normally in day 17-18 of postnatal development. In contrast, animals treated with the other three hormones did not differ significantly from controls.

We have previously shown $(4,5)$ that sialic acid and fucose are major determinants of the changes in the microvillus membrane binding of ${ }^{125}$ I-labeled WGA, UEA 1 , and PNA associated with weaning in the rat. In the experiments shown in Table 4,
Table 2. Effect of hormone administration on sialic acid and fucose content of microvillus membranes of suckling rat small intestine

\begin{tabular}{|c|c|c|c|}
\hline Group* & $\begin{array}{r}\text { Sialic acid } \\
\text { (nmoles/m } \\
\text { pro }\end{array}$ & $\begin{array}{l}\text { Fucose } \\
\text { membrane } \\
\text { in) }\end{array}$ & $\begin{array}{l}\text { Sialic/ } \\
\text { fucose }\end{array}$ \\
\hline \multicolumn{4}{|l|}{13 day old; injected with } \\
\hline Saline (control) $(n=4)$ & $112.9 \pm 16.5$ & $28.0 \pm 3.7$ & 4.0 \\
\hline Cortisone $(n=4)$ & $\begin{array}{c}79.6 \pm \\
12.7 \dagger\end{array}$ & $39.6 \pm 4.5 \dagger$ & 2.0 \\
\hline Thyroxine $(n=4)$ & $98.3 \pm 13.8$ & $40.8 \pm 6.7 \dagger$ & 2.4 \\
\hline $\operatorname{EGF}(n=4)$ & $95.1 \pm 10.7$ & $28.6 \pm 6.1$ & 3.3 \\
\hline Insulin $(n=3)$ & $96.4 \pm 16.8$ & $25.6 \pm 3.0$ & 3.8 \\
\hline \multicolumn{4}{|l|}{ Noninjected } \\
\hline $8-10$ day old $(n=5)$ & $126.8 \pm 14.2$ & $27.4 \pm 7.9$ & 4.6 \\
\hline 18 day old $(n=5)$ & $79.2 \pm 11.3$ & $37.2 \pm 9.1$ & 2.1 \\
\hline 40 day old $(n=5)$ & $45.9 \pm 3.6$ & $165.1 \pm 20.1$ & 0.3 \\
\hline
\end{tabular}

* Treatments with the various hormones are described in "Materials and methods." Noninjected animals were sacrificed at the specified ages. A more detailed assessment of the age-related change in sialic acid and fucose content of the microvillus membranes has been published (5).

Values are mean \pm SD for the indicated number of animals. Significantly different from control (saline): $\uparrow p<0.025$.

Table 3. Effect of hormone administration on ${ }^{\beta}$ HJfucose incorporation into microvillus membranes of rat intestine

\begin{tabular}{cc}
\hline & $\begin{array}{c}\text { incorporation into microvillus membranes of rat intestine } \\
\left(\mathrm{cpm} \times 10^{-3} / \mathrm{mg}\right. \\
\text { protein })\end{array}$ \\
\hline Group* & \\
\hline 13 day old; injected with & $4.1 \pm 0.4$ \\
Saline (control) & $12.5 \pm 2.1 \dagger$ \\
Cortisone & $5.4 \pm 1.9$ \\
Thyroxine & $5.1 \pm 1.1$ \\
EGF & $5.3 \pm 2.2$ \\
Insulin & \\
Noninjected & $3.2 \pm 0.3$ \\
8 day old & $16.3 \pm 2.9$ \\
18 day old & $31.2 \pm 6.2$ \\
40 day old & \\
\hline
\end{tabular}

* The animals were treated with the various hormones as described in "Materials and methods." After fasting overnight, the animals were injected intraperitoneally with $0.6 \mu \mathrm{Ci}$ of $\left[{ }^{3} \mathrm{H}\right]-(5,6)$-fucose per gram of body weight and sacrificed 90 min later (see "Materials and methods" for details).

Values are mean \pm SD from four animal preparations for each group. Significance of difference between control (saline) and hormone-treated groups: $\uparrow p<0.001$.

Table 1. Growth and intestinal disaccharidases in control and hormone-injected rats

\begin{tabular}{lcccc}
\hline \multicolumn{1}{c}{ Group* } & $\begin{array}{c}\text { Body wt }(\mathrm{g}) \\
\text { on 4th } \\
\text { injection day }\end{array}$ & $\begin{array}{c}\text { Intestinal } \\
\text { wt }(\mathrm{g}) \text { at } \\
\text { sacrifice }\end{array}$ & $\begin{array}{c}\text { Sucrase } \\
\text { activity } \\
(\mu \mathrm{mol} / \mathrm{min} / \mathrm{mg} \mathrm{MVM})\end{array}$ & $\begin{array}{c}\text { Lactase } \\
\text { activity } \\
\text { protein } \dagger\end{array}$ \\
\hline Saline $(n=4)$ & $16.4 \pm 0.74$ & $2.69 \pm 0.29$ & $0.02 \pm 0.02$ & $0.54 \pm 0.05$ \\
Cortisone $(n=4)$ & $12.1 \pm 2.00 \ddagger$ & $2.05 \pm 0.24 \ddagger$ & $0.21 \pm 0.03 \S$ & $0.77 \pm 0.11 \ddagger$ \\
Thyroxine $(n=4)$ & $15.9 \pm 0.81$ & $2.67 \pm 0.30$ & $0.13 \pm 0.03 \uparrow$ & $0.59 \pm 0.09$ \\
EGF $(n=4)$ & $16.6 \pm 0.76$ & $3.01 \pm 0.13$ & $<0.02$ & $0.69 \pm 0.09 \|$ \\
Insulin $(n=3)$ & $16.1 \pm 0.93$ & & $<0.02$ & $0.49 \pm 0.04$ \\
\hline
\end{tabular}

* All animals were 13 days old at sacrifice. Treatments with the various hormones are described in "Materials and methods."

+ The microvillus membranes (MVM) were prepared (14) from the proximal two-thirds of the small intestine as described in "Materials and methods." Yield and enrichment of lactase activity were 20.3-24.3 and 14.1-16.9, respectively, with no signifciant differences between control and hormone-treated animals.

Values are mean \pm SD for the indicated number $(n)$ of animals. Significantly different from control (saline): $\ddagger p<0.02 ; \S p<0.001 ; \uparrow p<0.005$; $\| p<0.02$. 
Table 4. Effect of hormone administration on ${ }^{125}$ I-lectin binding to microvillus membranes of suckling rat intestine

${ }^{125} \mathrm{H}$-lectin bound $(\mu \mathrm{g} / \mathrm{mg}$ membrane protein)*

\begin{tabular}{lll} 
& \multicolumn{2}{c}{ membrane protein) } \\
\cline { 2 - 3 } Group & \multicolumn{1}{c}{ UEA } & WGA \\
\hline 13 day old; injected with & & \\
Saline (control) & $2.6 \pm 0.3$ & $23.3 \pm 0.9$ \\
Cortisone & $4.3 \pm 0.9 \dagger$ & $11.9 \pm 2.5 \ddagger$ \\
Thyroxine & $3.8 \pm 1.0 \dagger$ & $20.2 \pm 0.7 \dagger$ \\
EGF & $2.1 \pm 0.8$ & $21.9 \pm 3.7$ \\
Insulin & $2.9 \pm 0.2$ & $21.5 \pm 2.3$ \\
& & \\
Noninjected & & \\
8-10 day old & $1.2 \pm 0.4$ & $25.7 \pm 4.3$ \\
18 day old & $3.8 \pm 0.6$ & $20.6 \pm 3.8$ \\
40 day old & $9.7 \pm 1.3$ & $15.2 \pm 3.7$ \\
\hline
\end{tabular}

* The lectin binding assays were performed as described in "Materials and methods." Values in saline-injected controls were equal to those in 13-day-old noninjected (not shown).

Values are mean \pm SD from four to six preparations. Significance of difference between control and hormone-treated groups: $\dagger p<0.05$; $\ddagger p$ $<0.001$.

Table 5. Binding of ${ }^{125}$ I-labeled PNA to native and desialylated microvillus membranes

\begin{tabular}{llcc}
\hline \multirow{1}{c}{ Group* } & $\begin{array}{c}\text { Membrane } \\
\text { preparation } \dagger\end{array}$ & $\begin{array}{c}{ }^{125} \text { I-PNA bound } \neq \\
(\mu \mathrm{g} / \mathrm{mg} \text { protein })\end{array}$ & $\begin{array}{c}\text { Sialic acid } \\
(\mathrm{nmol} / \mathrm{mg} \\
\text { protein) }\end{array}$ \\
\hline Saline (control) & Native & $19.9 \pm 1.1$ & $127.0 \pm 14.2$ \\
& Neuraminidase & $61.1 \pm 1.2$ & 30.7 \\
Cortisone & Native & $38.0 \pm 4.9 \S$ & $91.2 \pm 10.3 \S$ \\
& Neuraminidase & $58.2 \pm 4.7$ & 39.1 \\
\hline
\end{tabular}

* The experimental groups are described in "Materials and methods."

$\dagger$ For desialylation, $2.0 \mathrm{mg}$ of membrane protein was incubated with $1.0 \mathrm{U}$ of neuraminidase from $C$. perfrigens for $2 \mathrm{~h}$ at $37^{\circ} \mathrm{C}$ and centrifuged at $42,000 \times \mathrm{g}$ for $30 \mathrm{~min}, 4^{\circ} \mathrm{C}$. The pellet was suspended in $5 \mathrm{ml}$ of 50 $\mathrm{mM}$ sodium maleate buffer $\mathrm{pH} 6.5$ and centrifuged as before. The final pellet was suspended in $1 \mathrm{ml}$ of sodium maleate buffer.

$\ddagger$ For the binding assays, $10 \mu \mathrm{g}$ of membrane protein was incubated with $1.9 \mu \mathrm{g}$ of ${ }^{125} \mathrm{I}$-PNA (sp. act. $23,403 \mathrm{cpm} / \mu \mathrm{g}$ protein) in a total volume of $200 \mu \mathrm{l}$ (see "Materials and methods").

Values are mean \pm SD of four to five animal preparations, except for sialic acid in neuraminidase-treated membranes (three preparations) Significance of difference between control and cortisone groups: $\S p<$ 0.01 .

we assessed the binding of ${ }^{125}$ I-labeled $\mathrm{UEA}_{\mathrm{I}}$ and WGA to membranes from control and hormone-treated animals, and compared the results with the normal developmental change in binding (5). Both cortisone and thyroxine increased UEA, binding significantly over control, reaching the levels found normally in postnatal day 17-18. In contrast, cortisone and thyroxine differed markedly with respect to WGA binding: only cortisone caused a large decrease in the binding of this lectin, lowering it to the levels found in the mature membranes of weanling animals. EGF and insulin did not induce significant alterations in the binding of these two lections.

The profound effect of cortisone-induced desialylation on the membrane reactivity to lectins was further demonstrated in the experiments shown in Table 5 , in which we measured PNA binding to the native membranes before and after treatment with neuraminidase. In comparison to controls, cortisone increased PNA binding to the native membranes by about 2-fold ( $p<$ $0.001)$. This change in binding was opposite that normally found in weaning rats $(4,5)$. The differences in PNA binding between controls and cortisone-treated animals were, however, erased by neuraminidase treatment of the membranes. In control rats, this treatment removed approximately $75 \%$ of the sialic acid and raised PNA binding about 3-fold, whereas in the cortisone group removal of $58 \%$ of the lower content of sialic acid brought about a 1.4-fold increase in binding. The amount of residual sialic acid was about equal in both membrane preparations.

\section{DISCUSSION}

The period of weaning in suckling rats lasts for about a week (7), and is associated with a marked reduction in content of sialic acid in native and delipidated microvillus membranes (5). Of the four hormones tested in this study, only cortisone stimulated this developmental desialylation process. Furthermore, although the membrane sialic acid content in cortisone-treated animals corresponded to levels normally found in postnatal day 17-18 (5), the simultaneous changes in lectin binding to the membranes suggested subtle qualitative differences between developmental and cortisone-induced desialylation. First, cortisone decreased WGA binding well beyond day 17-18 to levels normally found in weanling rats. Although WGA exhibits high specificity for both terminal nonreducing $\mathrm{N}$-acetylglucosamine and sialic acid, we have previously shown (5) that the developmental decrease in WGA binding occurs in neuraminidase-sensitive sites of the membrane. Therefore, cortisone treatment seemed to have a particularly strong action on removal of sialic acid residues from certain oligosaccharide classes. Second, PNA binding to unsubstituted sites in rat intestinal membranes virtually disappears at about the time of weaning (4). We have presented data suggesting that this is due to increasing substitution through fucosylation (5), and perhaps also through other glycosylation events associated with intestinal maturation (4; unpublished data). The cortisone-induced increase in PNA binding could therefore be explained through failure by the hormone to stimulate the glycosylation of certain PNA binding oligosaccharides. Alternatively, the hormone might stimulate the biosynthesis of incompletely glycosylated PNA binding glycopeptides.

Cortisone administration to pregnant rats induced an acceleration of intestinal maturation in utero (18). As part of this action, an increase in the binding of UEA to the microvillus membrane was noted. In our studies, the effects of cortisone and thyroxine treatments on fucose content of the membrane were commensurate with a 5- to 6-day acceleration of age-related intestinal maturation. Both hormones raised the total fucose content and the binding of $\mathrm{UEA}_{\mathrm{I}}$ to the same levels, but only cortisone stimulated the $\left[{ }^{3} \mathrm{H}\right]$-fucose incorporation into the microvillus membrane after a 90 -min pulse of the labeled sugar. This suggested that certain membrane fractions, probably subjected to rapid rates of fucosylation, were sensitive to cortisone, but not to thyroxine.

EGF and insulin in pharmacologic doses are known to stimulate intestinal differentiation and maturation in suckling mice (11-13). These effects, however, have not been demonstrated in suckling rats. EGF injections to 2-wk-old rats resulted in increases in intestinal weight, lactase activity, and calcium transport, but had no effect on sucrase and maltase activities (13). The effect on lactase activity was confirmed in our studies. Thus, in suckling rats, EGF might stimulate mucosal growth without altering the developmental program of epithelial differentiation. Such a mechanism could explain the lack of action of the hormone on the differentiation-associated changes in the sialic acid and fucose composition of the microvillus membranes. This interpretation, however, is based on responses to the hormonal doses used. Results could differ significantly under various experimental conditions.

In conclusion, administration of cortisone to suckling rats accelerates the maturational shift from sialylation to fucosylation of microvillus membrane oligosaccharides. However, there are qualitative differences between developmental and cortisoneinduced desialylation, suggesting that cortisone does not homog. 
enously stimulate the developmental process of glycosylation in suckling rats. At the doses used in these studies, thyroxine administration has a very weak effect on these developmental changes in membrane glycosylation, while EGF and insulin have no demonstrable effect.

\section{REFERENCES}

1. Etzler ME Branstrator ML 1979 Cell surface components of intestinal epithelial cells and their relationship to cellular differentiation. In: Development of Mammalian Absorptive Processes. Ciba Foundation Series 70, New York. pp 51-68

2. Pang KY. Udall JN, Newman A, Walker WA 1983 Development of the intestinal cell surface: lectin identification of carbohydrate component differences. Gastroenterology 84:1270

3. Yeh KY. Moog F 1984 Biosynthesis and transport of glycoproteins in the small intestinal cpithelium of rats. I. Developmental changes and effect of hypophysectomy. Dev Biol 101:446-462

4. Mahmood A. Torres-Pinedo R 1983 Postnatal changes in lectin binding to microvillus membranes from rat intestine. Biochem Biophys Res Comm 113:400-406

5. Torres-Pinedo R. Mahmood A 1984 Postnatal changes in biosynthesis of microvillus membrane glycans of rat small intestine. I. Evidence of a developmental shift from terminal sialylation to fucosylation. Biochem Biophys Res Comm 125:546-553

6. Kretchmer N. Latimer JS. Raul F. Berry K. Legum C, Sharp HL 1979 Sucrase and cellular development. In: Devclopment of Mammalian Absorptive Processes. Ciba Foundation Series 70. New York. pp 117-131

7. Henning SJ 1981 Postnatal development: coordination of feeding, digestion. and metabolism. Am J Physiol 241:G-199-214

8. Henning SJ, Kretchmer N 1973 Development of intestinal function in mammals. Enzyme 15:3-23

9. Moog F 1979 Differentiation and redifferentiation of the intestinal epithelium and its brush border membrane. In: Development of Mammalian Absorptive Processes. Ciba Foundation Symposium 70 (new series). Excerpta Medica, New York, pp 3 \-50

10. Daniels VG, Hardy RN, Malinowska KW, Nathanielsz PW 1973 The influence of exogenous steroids on macromolecular uptake by the small intestine of the new-born rat. J Physiol (Lond) 229:681-695

11. Malo C Menard D 1982 Influence of epidermal growth factor on the development of suckling mouse intestinal mucosa. Gastroenterology 83:28-35

12. Menard D, Malo C, Calvert R 1981 Insulin accelerates the development of intestinal brush border hydrolytic activities of suckling mice. Dev Biol $85: 150-155$

13. Oka Y, Ghishan FK, Greene HL, Orth DN 1983 Effect of mouse epidermal growth factor/urogastrone on the functional maturation of rat intestine. Endocrinology 112:940-944

14. Schmitz J, Presier H, Maestracci D, Ghosh BK, Cerda JJ, Crane RK 1973 Purification of the human intestinal brush border membrane. Biochem Biophys Acta 323:98-112

15. Lowry OH, Rosebrough NJ, Farr AL, Randall RJ 1951 Protein measurement with the Folin phenol reagent. J Biol Chem 193:265-275

16. Dische Z, Shettles LB 1948 A specific color reaction of methylpentoses and a spectrophotometric micromethod for their determination. J Biol Chem 179:595-603

17. Warren L 1959 The thiobarbituric acid assay of sialic acid. J Biol Chem 234:1971-1975

18. Pang KY. Newman AP, Udall JN, Walker WA 1983 In utero maturation of the enterocyte surface. Pediatr Res 17:138A 